\title{
Overview of scientific publication: challenges for national editors
}

\author{
Maria da Graça Oliveira Crossettia
}

DOl: http://dx.doi.org/10.1590/1983-

1447.2014.04.52487

The scientific publication process is quite complex in that it is eminently human, conveyed in an intricate network of subjects such as authors, editors-in-chief, associate editors, ad hoc reviewers, funding entities, scientific associations and publishers, among other institutions. This makes the process both unique and plural, since these stakeholders have different interests in terms of scientific publication.

These interests are sometimes veiled, but perceived mainly by those who bear the responsibility of offering the scientific community from a certain field of knowledge a quality journal, that is, those who outline competitive editorial management. Promptness, agility, high impact indexes, indexation in international databases and visibility are just some of the excellence criteria on the agenda of Editors-in-Chief and Editorial Boards, under penalty of losing vital ground gained in the scientific world.

It is through these channels that authors select a journal in which to publish their scientific articles, and rightly so, since they are disseminating the construction of knowledge or science in natura in order to transform realities, re(direct) views and/or paradigms.

However, it is important to note that these plural expectations are not always consistent with the reality of what goes on behind the scenes ${ }^{(1)}$ during the scientific publication process. This often goes unnoticed by authors and particularly funding agencies and/or those responsible for imposing criteria and metrics that do not always consider the everyday operations of journals in their efforts to ensure the quality of the product offered to the scientific community.

It is against this backdrop that I conducted a national overview of scientific publication: challenges for editors.

In recent years, criteria and strategies to ensure the visibility of national journals have been a continuous feature of debates at scientific publishing events. These include criteria adopted to classify journals, such as Qualis CAPES in the field of nursing ${ }^{(2)}$, and those recently established to maintain and/or submit new journals to SciELO Brasi( ${ }^{(3)}$, as well as a project to internationalize CAPES' Brazilian scientific journals, which proposes the adoption of international publishers with a view to improving production, hosting and visibility. These fall into three major categories: internationalization, professionalization and financial autonomy.

Although this intention is noble and in line with the goal of visibility and consumption of Brazilian researcher's scientific articles by the international community, an analysis of these journals reveals that their creators lack understanding of the reality of Editors-in-Chief responsible for editorial management. There are relevant regional conditions specific to Brazilian research that must be carefully considered in these analyses given their importance in the national context.

\footnotetext{
a PhD in Nursing Philosophy Nursing from the Universidade Federal de Santa Catarina (UFSC). Lecturer on Fundamental Nursing at the Universidade do Estado do Rio de Janeiro (UERJ). Permanent Professor on the Graduate Studies Nursing Program at UFRGS. Professor on the Graduate Studies Nursing Program at UFRGS. Full Professor at the UFRGS Nursing School. Coordinator of the NECE/UFRGS. Coordinator of the Editing Committee for the Revista Gaúcha de Enfermagem. Porto Alegre, Rio Grande do Sul, Brazil
} 
Countless editors and/or national publications have long experienced a variety of difficulties in terms of editorial management and, consequently, in honoring their commitments to authors and the scientific community.

A national scientific publication that exemplifies internationalization, professionalization and financial autonomy presents real challenges for editors-in-chief and/or publications in terms of maintaining this status and perhaps insertion into the international publications market.

In deference to these issues and in order to achieve its goals, the Revista Gaúcha de Enfermagem (Rio Grande do Sul Nursing Journal) has made volume 35 no. 4 of December 2014 available to the nursing scientific community. Furthermore, it reiterates that all stakeholders responsible for its publication/editing do so from a human, social and scientific interactionist perspective.

\section{REFERENCES}

1. Conceição MIG. Nos bastidores da editoração. Psic: Teor Pesq. 2006;22(1):iii-iv.

2. Coordenação de Aperfeiçoamento de Pessoal de Nível Superior. Diretoria de Avaliação (BR). Documento de área 2013, área de avaliação: Enfermagem, Brasilia; [citado 2014 dez 18] 2013. Disponivel em: http://qualis.capes.gov.br/webqualis/publico/documentosDeArea.seam?conversationPropagation=begin

3. Scientific Electronic Library Online (BR). Critérios, política e procedimentos para a admissão e a permanência de periódicos científicos na coleção SciELO Brasil. São Paulo; [citado 2014 dez 18] 2014. Disponível em: http://www.scielo.br/avaliacao/20141003NovosCriterios_SciELO_Brasil.pdf 